\title{
The Zeroing Issue: a critical analysis of Softwood V
}

\author{
CHAD P. B OW N \\ Department of Economics and International Business School, MS 021, Brandeis University, PO Box 549110, \\ Waltham, MA, 02454-9110 USA \\ Email:cbown@brandeis.edu
}

ALAN O. SYKES

Stanford Law School, Stanford, CA

\begin{abstract}
This paper addresses the issues that came before the Appellate Body in the Softwood V dispute, concerning an affirmative antidumping determination by the US Department of Commerce. The paper addresses both the original Appellate Body opinion in the dispute, and the later opinion reviewing the compliance panel findings. We focus primarily on the 'zeroing' issue in 'transaction-to-transaction (T-T)' calculations of dumping, and briefly on two other cost-allocation issues. In general, we are ambivalent about the Appellate Body's approach to the zeroing issue. On the one hand, zeroing inflates dumping margins without any sound economic rationale for doing so. On the other hand, zeroing has been a standard administrative practice for many years and the ADA does not clearly prohibit it. The Appellate Body's legal analysis of the matter in $\mathrm{T}-\mathrm{T}$ cases, in particular, rests on shaky premises. We also consider the wisdom of addressing the zeroing issue in piecemeal fashion through what has proven to be a lengthy sequence of narrow decisions.
\end{abstract}

\section{Introduction}

The softwood-lumber dispute between the United States and Canada has been one of the longest-running trade disputes in history, producing extensive litigation in the United States, the NAFTA, and the WTO, spanning questions of subsidization, dumping, and injury. For the moment at least, the dispute appears to have been settled by the entry into force of the Softwood Lumber Agreement between the two disputants, under which Canada has agreed to impose a tiered system of export taxes, quantitative controls, and export licenses on its softwoodlumber exports. ${ }^{1}$ The particular dimension of the dispute on which we focus is

Thanks to Meredith Crowley, Edwin Vermulst, Petros Mavroidis, Joel Trachtman, David Palmeter, and ALI conference participants in Geneva for useful comments on an earlier draft. All remaining errors are our own.

1 See Notification of Mutually Agreed Solution, WT/DS264/29 G/L/566/Add.1 G/ADP/D42/2, November 16, 2006 (covering all outstanding WTO softwood disputes: DS236, DS247, DS257, DS264, DS277, and DS311). 
the complaint brought to the WTO by Canada in 2002 concerning an affirmative antidumping duty determination by the United States Department of Commerce (Commerce). This case is commonly termed 'Softwood V'; the WTO decisions in Softwood I-IV and Softwood VI address other aspects of the broader softwood-lumber dispute.

In Softwood V, Canada challenged numerous aspects of the dumping determination by Commerce as being inconsistent with the Antidumping Agreement (ADA), including the decision to initiate the investigation, the like-product determination, and various adjustments to the dumping calculations that Commerce made or refused to make. ${ }^{2}$ The aspect of Canada's case that became central before the Appellate Body, however, was the practice of 'zeroing' by Commerce in the calculation of dumping margins, a practice that we explain below. Canada's original complaint challenged the practice of zeroing in 'weighted average to weighted average' (W-W) calculations of antidumping duties. After Canada prevailed on this challenge before the panel ${ }^{3}$ and the Appellate Body, ${ }^{4}$ Commerce purported to comply with the ruling by shifting its method of calculation to the 'transaction-to-transaction' (T-T) method, again employing the practice of zeroing. Canada challenged the resulting determination before an Article 21.5 compliance panel, where the United States prevailed. ${ }^{5}$ The Appellate Body reversed the panel, and held that zeroing was also impermissible in T-T calculations, at least in the context of original investigations. $^{6}$

Softwood V is neither the first nor the last WTO dispute in which zeroing has been a central issue. The Appellate Body has now addressed zeroing in four other opinions, ${ }^{7}$ with perhaps still more to come. Further challenges to US zeroing practices are pending in cases brought by Mexico, Ecuador, and Thailand. In addition, the Appellate Body has not yet addressed the use of zeroing in the 'weighted-average-to-transaction' (W-T) method of calculating dumping

2 See United States - Final Dumping Determination on Softwood Lumber from Canada, WT/ DS264/R, April 13, 2004 (hereafter Panel Report).

3 Ibid.

4 See United States - Final Dumping Determination on Softwood Lumber from Canada, Report of the Panel, WT/DS264/AB/R, August 11, 2004 (hereafter AB Report).

5 See United States - Final Dumping Determination on Softwood Lumber from Canada, Recourse to Article 21.5 of the DSU by Canada, WT/DS264/RW, April 3, 2006 (hereafter Compliance Panel Report).

6 United States - Final Dumping Determination on Softwood Lumber from Canada, Recourse to Article 21.5 of the DSU by Canada, WT/DS264/AB/RW, August 11, 2006 (hereafter Compliance AB Report).

7 See European Communities - Anti-Dumping Duties on Imports of Cotton-Type Bed Linen from India, WT/DS141/AB/R, March 1, 2001; United States-Sunset Review of Antidumping Duties on Corrosion-Resistant Carbon Steel Flat Products from Japan, WT/DS244/AB/R, December 15, 2003; United States - Laws Regulations and Methodology for Calculating Dumping Margins ('Zeroing'), WT/ DS294/AB/R, April 18, 2006; United States-Measures Relating to Zeroing and Sunset Reviews, WT/ DS322/AB/R, January 9, 2007. 
margins, which is permitted under certain special and imprecisely defined circumstances.

The focus of this paper will be on the zeroing issue, and on the broader question whether the Appellate Body's incremental approach to the practice of zeroing is procedurally desirable from a legal and economic standpoint. In brief, we are ambivalent about the Appellate Body's approach to the zeroing issue. On the one hand, zeroing inflates dumping margins without any sound economic rationale for doing so. On the other hand, zeroing has been a standard administrative practice for many years and the ADA does not clearly prohibit it. The Appellate Body's legal analysis of the matter in T-T cases, in particular, rests on shaky premises. We also discuss the wisdom of addressing the zeroing issue in piecemeal fashion through what has proven to be a lengthy series of narrow decisions.

In addition to the discussion of zeroing, we touch briefly on two cost-allocation issues that came before the Appellate Body in Softwood V. In both instances, the underlying practices by Commerce are questionable from an economic standpoint.

\section{Factual and legal issues and their disposition}

\section{The practice of zeroing and its effects}

Dumping occurs when export transactions occur at prices below 'normal' or 'fair' value, which is in turn computed with reference to home-market prices, thirdcountry prices, or estimated costs of production, depending on the circumstances. Roughly speaking, a 'dumping margin' measures the extent to which export prices fall below the selected benchmark for normal value. Exporters typically have multiple transactions with the importing country that is investigating dumping, however, and hence dumping margins in practice are almost invariably based on some 'average' amount of dumping. In computing this average, the investigating authority can treat transactions for which the export price is above normal value as 'negative dumping', so that the amount by which export prices exceed normal value in some transactions will offset the amount by which export prices fall below normal value in others, thereby lowering the average amount of dumping. The zeroing method of calculation treats all instances of 'negative dumping' as zero dumping, however, so that only the transactions in which the export price is below normal value 'count' in computing the numerator for purposes of averaging. The inevitable effect is to increase the computed average and thus also to increase any resulting antidumping duties.

To illustrate zeroing, suppose that the normal value for all export transactions is established to be 100 . Three export transactions occur at prices of 90, 100, and 110. The first of these transactions is 'dumped' because $90<100$. The other two are not. Nevertheless, the average price for the export transactions is 100 , exactly equal to normal value. Without zeroing, the magnitude of dumping for the three transactions would be computed as 10,0 , and -10 , so that the average amount of dumping across the three transactions would be zero $\{[10+0+(-10)] / 3\}$ and 
no antidumping duty could be imposed. With zeroing, by contrast, the transaction with the 'negative' dumping is treated as a transaction with zero dumping, and the 'average' amount of dumping is found to be 3 and $1 / 3\{[10+0+0] / 3\}$.

The technique of zeroing can be employed regardless of the exact method of calculating the magnitude of dumping. To explain how, we begin with Article 2.4.2 of the ADA:

Subject to the provisions governing fair comparison in paragraph 4 , the existence of margins of dumping during the investigation phase shall normally be established on the basis of a comparison of a weighted average normal value with a weighted average of prices of all comparable export transactions or by a comparison of normal value and export prices on a transaction-to-transaction basis. A normal value established on a weighted average basis may be compared to prices of individual export transactions if the authorities find a pattern of export prices which differ significantly among different purchasers, regions or time periods, and if an explanation is provided as to why such differences cannot be taken into account appropriately by the use of a weighted average-to-weighted average or transaction-to-transaction comparison.

Thus, as noted in the introduction, three methods of calculation are authorized 'during the investigation phase'. 8 The calculation shall 'normally' be W-W or $\mathrm{T}-\mathrm{T}$, with W-T allowed only under special circumstances. Those circumstances seemingly relate to cases of narrowly targeted dumping that is concentrated on particular 'purchasers, regions or time periods', but to date the W-T method has apparently been little used and no case involving zeroing with the W-T method has come before the Appellate Body.

In a W-W case, one might suppose that zeroing cannot occur because the dumping margin is based on a comparison between normal value and average rather than individual export prices. In fact, however, W-W cases often involve comparisons across several product categories, which are then aggregated to produce the average dumping margin. Zeroing can then occur if 'negative' dumping in one or more product-category comparisons is zeroed when computing the aggregate average. For example, suppose that widgets come in two models, $\mathrm{A}$ and $\mathrm{B}$. The normal value for model $\mathrm{A}$ is 50 , while the average export price is 60 . For model $\mathrm{B}$, the normal value is 80 and the average export price is 70 . Thus, model $\mathrm{B}$ is dumped and model $\mathrm{A}$ is not. The dumping margin for all widgets will be computed using the amount of dumping for model $\mathrm{A}$ and the amount for model B, weighted by the sales of each model, and divided by the total sales of both models. Zeroing treats the amount of dumping for model A as zero, while a calculation without zeroing will treat it as -10 . The resulting 'average' is plainly

8 This language hints at another set of issues: namely, whether different rules apply at other points in the process such as periodic reviews, sunset reviews, and new-shipper reviews. These issues have been raised in some of the other zeroing cases to come before the Appellate Body, but we will not address them here. 
higher with zeroing. Because the effect of zeroing in a W-W case results from zeroing the results for particular subcategories or 'models' of the broader product under investigation, it is sometimes termed 'model zeroing'.

The operation of zeroing in T-T cases is more transparent. The investigating authority will compare the prices of individual export transactions to 'comparable' transactions in the home country or a third country, or perhaps to cost of production. Whenever the individual export transaction price is above the benchmark for normal value, the amount of dumping is said to be zero rather than negative. Again, the inevitable effect is to raise the 'average' amount of dumping. When zeroing is used in a T-T case it is sometimes termed 'simple zeroing'.

\section{Zeroing in Softwood V: the initial phase}

In its original softwood-lumber investigation, Commerce investigated the six largest Canadian exporters and determined individual dumping margins for them. Smaller Canadian exporters received an 'all others' margin based on a weighted average of the margins for the six investigated companies. Export prices were based on a weighted average of transaction prices for each company within several product categories. Normal value was based on a weighted average of home-market-transaction prices for each product category, although for each company Commerce disregarded a number of lower priced home-market sales that were deemed to be below cost of production. The case was thus a W-W investigation, and in computing the average amount of dumping for the covered softwood products as a whole, Commerce employed zeroing. ${ }^{10}$

Before the softwood-lumber investigation was initiated by Commerce in April 2001, the Appellate Body had already held in EC-Bed Linen that the EC's practice of zeroing, in investigations using the W-W method, violated Article 2.4.2 of the ADA. EC-Bed Linen is discussed and analyzed in Janow and Staiger (2003). Predictably, therefore, Canada included a challenge to zeroing in the softwood case and brought a claim under Article 2.4.2 of the ADA that was largely identical to the one that had prevailed in EC-Bed Linen.

Before the panel and the Appellate Body, Canada focused on the language in Article 2.4.2 requiring that W-W comparisons encompass 'all comparable export transactions'. Zeroing, in Canada's view, effectively excluded some comparable export transactions from the comparison.

The United States argued that the obligation to use 'all comparable export transactions' simply meant that all export transactions involving comparable goods must be used in the calculation, and that it had fulfilled this obligation

9 The effect of zeroing on a W-T calculation is also obvious and might be termed simple zeroing. Whenever the individual-export-transaction price is above the weighted average that is used as the basis for normal value, zeroing treats the amount of dumping as zero rather than negative and the average amount of dumping across all export transactions will increase.

10 Additional details of the calculations may be found in Commerce's preliminary and final dumping determinations, 66 Fed. Reg. 56062 (November 6, 2001) and 67 Fed. Reg. 15539 (April 2, 2002). 
when it decomposed softwood lumber into subgroups of comparable products and used all of the export transactions for each subgroup in its analysis. Each subgroup had its own 'margin of dumping' based on the W-W comparisons. And once it computed dumping margins for each subgroup in accordance with the text, argued the United States, the ADA provided no further guidance as to how those dumping margins were to be aggregated to obtain an overall average margin for softwood products. Because the text was silent on the method of aggregation, zeroing was not precluded in the US view. The United States also pointed to the ADA standard of review under Article 17.6, which requires that if the ADA has more than one permissible interpretation, decisions by national authorities should be upheld if they rest on one of the permissible interpretations. Finally, the United States insisted that its interpretation of the ADA was confirmed by its negotiating history.

Not surprisingly, in light of the Appellate Body decision in Bed Linen, the panel sided with Canada. On appeal, the Appellate Body affirmed the panel. It framed the legal issue as follows: Under the view of the United States, 'dumping' can occur and 'margins of dumping' can be computed for subgroups of a product under investigation. Once 'all comparable export transactions' have been taken into account at the subgroup level, the obligation in Article 2.4.2 is met. Under Canada's view, 'dumping' can only occur for a product as a whole, and the 'margin of dumping' can only be determined for a product as a whole. When the single 'margin of dumping' is computed on the basis of zeroing, some of the 'comparable export transactions' are effectively disregarded.

After laying out the alternative views, the Appellate Body reaffirmed its conclusions in Bed Linen. It pointed to the text of GATT Article VI and to Article 2.1 of the ADA, both of which define dumping as a situation in which 'products' are sold below normal value. From this language, the Appellate Body inferred that 'dumping' only exists for a 'product as a whole', not for subgroups of a product. Likewise, dumping margins only exist for a 'product as a whole'. The text of Article 2.4.2 thus requires that 'all comparable export transactions' be used to compute the final dumping margin for the product as a whole, not just in the computations for product subgroups. Because the Appellate Body considered the text of Article 2.4.2 to be clear on the matter, the standard of review in Article 17.6 had no applicability - there was only one 'permissible interpretation' of Article 2.4.2. Likewise, the negotiating history and context of Article 2.4.2 had no relevance because the text was clear.

\section{Zeroing in Softwood V: the compliance phase}

Commerce responded to the Appellate Body ruling by recalculating the dumping margins for the Canadian producers. Rather than using a W-W method without zeroing, however, it shifted to a T-T method and employed zeroing once again.

Canada took the position that zeroing is impermissible in a T-T calculation, and brought the matter to a compliance panel under Article 21.5 of the DSU 
again under ADA Article 2.4.2, and also Article 2.4, which states in pertinent part that '[a] fair comparison shall be made between the export price and the normal value'. The panel rejected Canada's claim under the ADA, however, noting that the Appellate Body rulings in Bed Linen and Softwood V were expressly limited to W-W cases. Furthermore, in both decisions the Appellate Body had relied on the phrase 'all comparable export transactions' in the text of Article 2.4.2, which is linked to the W-W method of computation only - no similar language appears in the text with regard to the T-T method of computation. The panel also found that a general prohibition of zeroing in the ADA would lead to some other anomalies, such as a mathematical equivalence between W-W and W-T calculations.

The Appellate Body reversed. It concluded that, in a 'comparison of normal value and export prices on a transaction-to-transaction basis', the use of the plural 'export prices' in the first sentence of Article 2.4.2 'suggests that all of the results of the transaction-specific comparisons should be included in the aggregation'.11 The absence of the phrase 'all comparable export transactions' in reference to the T-T method was of no significance in the view of the Appellate Body. That phrase was simply intended to require that when investigating authorities break a product into subgroups for purposes of a W-W calculation, they must ensure that transactions are 'comparable' and that all of the relevant transactions are included. ${ }^{12}$ The Appellate Body was also of the view that to allow zeroing under one method of calculation but not another would mean that the results of the two methods would be 'systematically different', an anomalous situation given that both methods are intended to measure dumping. ${ }^{13}$ As for the suggestion that a complete prohibition on zeroing would render the W-W and W-T methods mathematically equivalent and thus deprive the W-T method of any utility, the Appellate Body noted, inter alia, that it was not ruling on zeroing in a W-T calculation, and that in any case the details of such a calculation were unclear because no such calculation had been made. The Appellate Body also rejected various other arguments put forward by the panel to bolster its position.

\section{Other issues and their disposition}

Two other issues came before the Appellate Body in its original review of the case. Both arose from the calculation of the Canadian producers' 'cost of production' by Commerce, an exercise that served as the basis for excluding below-cost homemarket transactions from the normal-value calculation.

First, for the producer Abitibi, Commerce insisted that its financial expenses be allocated among its various product lines (only some of which were covered by the softwood-lumber investigation) using the 'cost of goods sold' (COGS) method.

11 Compliance AB Report, $\uparrow 88$.

12 Ibid. $\uparrow 91$.

13 Ibid. $\uparrow 93$. 
This method would allocate Abitibi's total financial expenses to softwood-lumber production based on the proportion of softwood-lumber production in Abitibi's total cost of goods sold. Abitibi instead wished to use an allocation method based on the proportion of its capital assets devoted to softwood production (which, presumably, would have resulted in a smaller allocation of financial expenses and thus a lower cost of production). Its rationale for the alternative method was that softwood production required proportionally fewer capital assets than other production activities within the company, and thus its proper share of capitalfinancing costs was lower than the COGS method suggested.

Commerce rejected Abitibi's request. It stated that the COGS method was its standard practice for the allocation of financial expenses. Further, it argued that if capital expenses were higher for lines of production other than softwood products, that difference would be accounted for in the calculation through the depreciation rate - less interest expense would be allocated to softwood production to the degree that financial statements showed less capital depreciation in softwood production. ${ }^{14}$

Canada challenged this determination, but the panel ruled for the United States. The Appellate Body reversed the panel's legal conclusions. It focused on the text of Article 2.2.1.1, which provides in pertinent part that '[a]uthorities shall consider all available evidence on the proper allocation of costs'. The Appellate Body held that the term 'consider' imposes a substantive obligation on investigating authorities that goes beyond simply receiving evidence and reciting that it has been 'considered'. Rather, in appropriate circumstances, authorities may be obligated to compare allocation methods and evaluate their merits. The panel had held that Article 2.2.1.1 'does not require that investigating authorities compare various allocation methodologies', and thus had interpreted the text incorrectly. Having held that the panel applied the wrong legal standard, however, the Appellate Body did not complete the factual analysis as to whether Commerce had complied with Article 2.2.1.1.15

The second issue concerned the calculation of by-product revenues for the producer Tembec. The production of the softwood-lumber products under investigation yields wood chips as a by-product, which are used by the pulp and paper industry. The revenue from the sale of wood chips reduces the effective cost of production for softwood-lumber products. In calculating the appropriate cost offset for Tembec, Commerce used its internal-transfer prices for sales between its wholly owned sawmill and pulp-mill divisions. For another Canadian producer (West Fraser) that made sales to affiliated companies, however, Commerce had disregarded the stated prices as being not at 'arm's-length' and substituted market prices instead. Tembec urged Commerce to do the same for its interdivisional transactions, but Commerce refused. The panel upheld Commerce on this issue, 
finding that the two companies were not similarly situated and that Commerce had not departed from its normal practices in the case.

On appeal, the Appellate Body accepted arguendo Canada's legal claim that Commerce had an obligation to treat producers in even-handed fashion, and that it had to act consistently across cases and thus adhere to its standard practices without good reason to depart from them. But the Appellate Body further determined that the panel had made factual findings against Canada on these points, and saw no reason to interfere with those factual determinations on appeal. ${ }^{\mathbf{1 6}}$

\section{Analysis}

\section{Zeroing}

An economic perspective on zeroing

To begin our discussion of zeroing, it is perhaps useful to consider the rationale for zeroing that is put forward by its US proponents. They analogize dumping to speeding in a motor vehicle. When a motorist is caught speeding by a police officer, what matters is that the motorist is exceeding the speed limit at the time. There is no inquiry into the question of whether the motorist obeyed the speed limit on average, and no offset for speeding if the motorist was going below the speed limit at an earlier time. Zeroing is analytically equivalent in the view of its proponents - firms that dump should not enjoy any offset for the occasions on which they price above normal value.

Is this analogy apt? An economic perspective on accident law suggests that 'negligence' in general represents a failure to take cost-effective measures to reduce risks to others created by an actor's activities. Speed limits represent a legislative substitute for case-by-case inquiry into the costs and benefits of driving speed. Excessive speed is subject to sanction irrespective of prior behavior because the legislature has determined that each act of speeding creates an unacceptable level of risk.

Does each 'dumped' sale of a product create a similarly unacceptable risk of economic harm that deserves sanction, regardless of the pricing behavior of the firm in other transactions? To answer this question, one must embrace a theory of why dumping is worrisome in the first instance. But modern economic learning has difficulty explaining why dumping should be subject to sanction at all.

Price-discrimination dumping is a natural response by firms with market power facing separate markets with different elasticities of demand. It may also result quite naturally from volatile market conditions and exchange-rate fluctuations. 'Below cost' dumping, with 'cost' understood not as marginal or variable cost but as total cost including an allocation of capital and overhead costs, is common in many industries where cost and demand conditions fluctuate. Firms in a

16 Ibid. $\uparrow 159-180$. 
competitive industry will tend to break-even against average total cost in the 'long run', but in the 'short run' will often see prices that vary above or below average total cost. Consequently, most instances of dumping are perfectly normal and benign manifestations of ordinary market conditions. These points are hardly original to us, but have been made by other commentators too numerous to warrant citation.

Defenders of antidumping rules most commonly suggest that the rationale for them lies with concerns about monopolization, and that dumping is akin to what antitrust scholars term predatory pricing. Although it is true that national antidumping laws were originally pitched as an important supplement to antitrust policy, they have never been so in practice. A sensible anti-predation policy would utilize structural filters, examining only concentrated industries where a danger of monopolization is plausible. Yet, antidumping duties are routinely used in unconcentrated industries where monopolization concerns are fanciful. Likewise, a sensible anti-predation policy would make a serious effort to ascertain whether low prices are an attempt to drive out competitors rather than a normal market phenomenon. There would be no presumption against price discrimination, and any cost-based floors would be linked to marginal or variable costs rather than fully allocated costs. Modern antidumping laws lack these characteristics. Finally, for nations with sensible antitrust laws, even narrowly tailored antidumping laws aimed at predation would seem superfluous.

For these reasons, it is impossible to argue that antidumping law is a sensible component of antitrust policy. Indeed, Sykes (1998) argues that the antitrust rationale for antidumping laws was pretense from the very outset, and that such laws were understood by their early proponents to be a disguised form of protectionism for troubled industries.

If the overwhelming weight of economic commentary is correct, individual transactions at 'dumped' prices are generally of no concern whatsoever. They are simply not analogous to dangerous behaviors such as speeding that are properly subject to sanction. As a corollary, any policy or practice that reduces the incidence or magnitude of antidumping duties in the global economy might be deemed desirable. To the degree that a prohibition of zeroing reduces antidumping duties, such prohibitions may seem quite welcome from an economic standpoint.

This proposition is subject to a potentially important caveat. Although economic commentators are almost uniformly critical of antidumping law as a normative matter, economic analysis has made considerably less progress on the positive issue of why antidumping law is so survivable in the global trading system. If antidumping duties are indeed silly from a policy standpoint, why have trading nations not agreed to abolish them (just as they have been abolished internally in the United States and European Union)? One must entertain the possibility that they serve some useful political function. If so, perhaps the availability of antidumping remedies has some other salutary effect, such as the facilitation of 
trade concessions that might not otherwise be made (an explanation often given for safeguard measures). And should this be the case, one can no longer say with confidence that any Appellate Body ruling that lessens the use or magnitude of antidumping duties is economically desirable.

More generally, if one views the ADA as part of a sophisticated contract among WTO members that promotes their mutual political interests when melded with the rest of the WTO bargain, one cannot be sanguine about any Appellate Body decision that does violence to the objectives of the ADA. From this perspective, the economic soundness of the Appellate Body rulings against zeroing in Softwood $\mathrm{V}$ and in other cases turns closely on the question of whether the rulings are sound as a legal matter. To that question we now turn.

\section{The legality of zeroing}

In Softwood $\mathrm{V}$ and its other rulings on zeroing, the Appellate Body has held fast to its conventional emphasis on textualism, paying relatively little heed to the negotiating history of the text. We understand this practice, as well as the principle that inferences from an often-murky negotiating history should not be permitted to override clear textual mandates. Nevertheless, we have some quarrels with the analysis of the Appellate Body in Softwood V that are perhaps best motivated by placing the issue in some historical context.

The practice of zeroing is not some arcane and technical practice that went unnoticed before the ADA. To the contrary, numerous commentators had written about zeroing and the arguably pernicious effect that it has on dumping margins. ${ }^{17}$ Many of these same commentators had also written about other 'biases' in antidumping calculations. A common criticism was that investigating authorities (especially Commerce) routinely used W-T methods to calculate dumping margins. This method of calculating margins tends to produce findings of dumping as a matter of course when coupled with zeroing. In particular, imagine comparing a volatile time series to a moving average of itself. Some data points will be below the moving average and some above. If the moving average is used as normal value, and individual data points below average are 'dumping', then the W-T method (coupled with zeroing) will find dumping even if the time series that is the basis for normal value is identical to the time series of export prices!

Such issues were plainly known to the negotiators of the ADA. And on the use of the W-T method, the negotiators produced a text that curtailed it greatly. Under Article 2.4.2, margin calculations shall 'normally' be W-W or T-T, with the W-T method reserved for special cases of dumping targeted at particular 'purchasers, regions or time periods'.

17 See, e.g., the collection of papers in Boltuck and Litan (1991), particularly the papers by Palmeter and by Boltuck, Francois, and Kaplan. 
Thus, when the negotiators reached agreement on the elimination or curtailment of one of the well-known 'biases' in antidumping calculations, they were quite capable of embodying that agreement in the treaty text. Yet, in stark contrast to the express curtailment of W-T methods by the ADA, there are no references anywhere in the ADA to the practice of zeroing. The United States argued, and we have some sympathy for this position, that this lack of attention to zeroing means that the negotiators reached no consensus on this issue, at least in so far as zeroing might be used in W-W or T-T calculations.

A possible counterargument is that the negotiators did not clearly separate the issue of zeroing from the effects of the W-T method and instead conflated the two. Indeed, the 'bias' inherent in W-T calculations evaporates without zeroing. One might thus conjecture that when the negotiators curtailed the use of W-T methods, they believed that they had also addressed the issue of zeroing. The difficulty with this argument is that zeroing also has a clear effect on W-W (with product subgroups) and $\mathrm{T}-\mathrm{T}$ calculations as well. Were the negotiators simply oblivious to this fact? Or was the lack of attention to zeroing in these other calculation methods a manifestation of their inability to achieve agreement? We do not know the answers to these questions.

Against this backdrop, we turn to the Appellate Body's textual analysis, and its conclusion that the text unambiguously prohibits zeroing in both $\mathrm{W}-\mathrm{W}$ and $\mathrm{T}-\mathrm{T}$ cases. We agree that the text might be interpreted as prohibiting zeroing through general references to 'all comparable export transactions' and 'fair comparisons'. Yet it is difficult for us to accept that a prohibition on zeroing is the only possible reading of the text, and some of the Appellate Body's reasoning is troubling. For example, there can be no dispute that in both Bed Linen and the original Softwood $\mathrm{V}$ opinion, the Appellate Body placed great weight on the phrase 'all comparable export transactions' in holding that zeroing is prohibited under the W-W method. Yet, when the T-T method came before it in the compliance proceeding, the Appellate Body gave the back of the hand to the absence of this phrase in Article 2.4.2 in its reference to the T-T method. It insisted that the phrase 'all comparable export transactions' simply calls for comparability and comprehensiveness when product subgroups are used in a W-W calculation, and is not the basis for the prohibition on zeroing. This interpretation of the phrase 'all comparable export transactions', of course, was advanced by the United States in the original proceeding in support of its argument that the ADA did not prohibit zeroing in W-W cases! And if the phrase 'all comparable export transactions' is not about zeroing, as the Appellate Body suggests in its Softwood V compliance decision, then the textual basis for a prohibition on zeroing seems questionable indeed. The phrase 'fair comparison' in Article 2.4 simply begs the question of what is fair. And it seems quite a stretch to suggest that the use of the plural 'export prices' in the reference to the T-T method is enough to preclude zeroing.

Ultimately, the Appellate Body itself must fall back on nontextual arguments from policy, such as its claim that the drafters of the ADA would not have created 
an agreement under which W-W and T-T calculations yield 'systematically different' results because only one method allows zeroing. Even if the premise here is correct, it is equally compatible with the proposition that zeroing is acceptable in both W-W and T-T cases, as the United States maintained in Softwood V.

As a legal matter, therefore, we have considerable sympathy for the proposition that the text of the ADA is at least ambiguous regarding the use of zeroing in W-W and T-T calculations. In the face of that ambiguity, the United States had a strong argument that the deferential standard of review under Article 17.6 should be invoked.

\section{Incrementalism in Appellate Body decisionmaking}

In this section, we analyze how the Appellate Body has confronted the issue of 'zeroing' more broadly in the cases that have come before it (and may yet come before it). Its strategy has been to decide each case narrowly, and generally to disclaim any intent to rule on the question of zeroing as it may arise in other contexts. The result has been a long sequence of cases brought by numerous complainants to address zeroing in various settings - in W-W cases, in T-T cases, and perhaps someday in W-T cases - in the context of original investigations, periodic reviews, sunset reviews, and new-shipper reviews. This approach to decision making we term 'incrementalism'. Our objective is to assess the costs and benefits of incrementalism as one approach in the range of potential lawmaking strategies that the Appellate Body could adopt.

Incrementalism is, in a sense, one extreme of the distribution, where the other extreme might be for the Appellate Body to adopt a more comprehensive approach to zeroing at the onset of the issue in EC-Bed Linen. As a thought exercise, we examine the tradeoffs of a narrow, incrementalist approach when compared to a stark alternative - suppose the Appellate Body in EC-Bed Linen had undertaken to address the issue of zeroing comprehensively in all three methods of calculation as employed at all possible stages of the antidumping law process. It might, in theory at least, have announced an intention to address the issue comprehensively, sought briefs from all interested parties on all of the relevant issues, and then decided all of them once and for all at the outset.

In engaging in this thought experiment, we are putting to the side the obvious constraints of the DSU and the limitations on the scope of a proceeding contained in the terms of reference to a panel. Accordingly, we do not mean to suggest that the Appellate Body necessarily has the legal authority to proceed in fully comprehensive fashion under current WTO law. We do note, however, that even within existing constraints the Appellate Body has some leeway to foreshadow decisions on other issues through dicta and through legal analysis that has inevitable logical implications for issues that may arise in future disputes. Thus, if one were to conclude that a more comprehensive approach to decisionmaking were desirable, the Appellate Body has some significant leeway to move in that direction. 


\section{Some advantages of incrementalism}

A complete economic treatment of the choice between incremental and comprehensive approaches to decisionmaking would require a formal theoretical model, and we will not undertake to construct one here. We nevertheless sketch the basic set of assumptions needed to examine the tradeoffs involved, and we explore their implications informally. First, the analysis must contemplate multiple periods to allow for the possibility of sequential decisionmaking by judges. ${ }^{18}$ Furthermore, the analysis must assume that judges face uncertainty when making their decisions as to the correct interpretation of the law, and that there are costs associated with errors in judicial rulings. In other words, rulings that are legally correct are also 'efficient'. It is also natural to assume that there is a negative relationship between the narrowness of the issue before the judge and the amount of uncertainty the judge faces - i.e., the more narrow the issue, the smaller the uncertainty and the more likely the judge makes a correct ruling, other things being equal. Lastly, it is natural to assume that the likelihood of error in any context can be reduced if the decisionmaker acquires more information (legal briefs, facts, etc.) and if the decisionmaker spends more time on the decision. Both of these options, however, are costly.

With these assumptions, a clear benefit to incrementalism as a law-making strategy in the judicial process is that it is parsimonious in the information required to decide cases holding constant the probability of error. Likewise, holding constant the amount of 'information' available to the decisionmaker and the time spent in deciding the case, incrementalism is less likely to result in error.

An additional benefit to incrementalism may arise if we extend the analysis to assume judges also have personal biases - i.e., personal preferences that differ from what is legally correct - which may further cause decisions to deviate from correct rulings. ${ }^{19}$ This is arguably an important consideration in the zeroing cases that are a subset of WTO litigation over the politically charged issue of antidumping. In line with this assumption, one could imagine a scenario in which Appellate Body members hold a personal bias either against antidumping measures (predisposed to complainants challenging another country's use of antidumping policy) because of its protectionist nature and lack of grounding in any economics or, alternatively, in favor of antidumping measures (predisposed to respondents being challenged) as a policy of fairness that governments require to maintain their political ability to engage in the WTO at all. A potential benefit of incrementalism as a lawmaking rule in this context is that it leads to rulings that are limited in

18 The models developed by Gennaioli and Shleifer $(2007 \mathrm{a}, \mathrm{b})$ are built on similar foundational assumptions, though their analysis is structured to examine the efficiency properties of different judicial lawmaking rules from the incrementalist rule under discussion here. We discuss the insight of these models and relevance for incrementalism in more detail below.

19 This assumption is common to the Gennaioli and Shleifer (2007a, b) models, which assume that judges hold personal 'biases' that deviate away from efficient rulings in favor of different types of disputants, and these biases vary across the population of judges. 
scope. Over time, if various biases in incremental rulings tend to 'cancel out', the potential for deviation from efficiency is lessened. ${ }^{20}$

A final institutional benefit to incrementalism may be that it is more likely to allow the Appellate Body to avoid being accused of engaging in 'judicial activism'. In the context of the WTO and the political trade-offs that it confronts in maintaining legitimacy in the eyes of its members, a perceived virtue to incrementalism is thus 'judicial restraint'.

If we were to stop here, incrementalism would seem an obviously superior approach to decisionmaking. But it remains to consider some items on the other side of the ledger.

\section{Incrementalism and resource costs of litigation}

One cost of incrementalism relates to the resource costs of litigation, as these can be substantial in the WTO system. In this context, there are at least two sets of costs to examine - the costs to the potential litigants themselves, as well as the resource costs to the WTO institution.

The first costs are the resources expended by the litigants involved in the additional cases that need to be litigated to fully flesh out the relevant law. A firstorder concern is that resolving a legal issue incrementally, as opposed to all at once, can lead to increased use of litigant resources if there are substantial fixed costs to the litigants associated with each new dispute. For example, a fixed cost arises if the litigants in the subsequent cases are different from the litigants in the first case, as the legal team in each subsequent case will also need to relearn the issues critical to the first ruling. A fixed cost may also exist even if the litigants are the same, given the longevity of DSU litigation and that there is likely to be turnover within a legal team (likely to be within a government agency) for a number of reasons, including ongoing changes in governments associated with elections, and so forth. ${ }^{21}$

In addition to the potential inefficient use of resources, the existence of substantial litigation costs may also create uneven patterns in the utilization of the

20 This relates to some extent to the analysis provided in Gennaioli and Shleifer (2007a, b), who consider two period models in which a judge in the first period makes a legal decision that establishes a precedent. In the second period, the authors examine equilibria under two different assumptions on legal rulemaking. In Gennaioli and Shleifer (2007a), the authors focus on a second-period legal rule of 'distinguishing', in which a second ruling can modify an existing precedent by introducing an additional dimension along which to interpret facts. In Gennaioli and Shleifer (2007b), the authors focus on a secondperiod legal rule of 'overruling', not by introducing another dimension along which to rule, but by merely allowing a new judge to change the first ruling. Their results are that the lawmaking strategy of distinguishing has beneficial evolutionary properties (even in the presence of biased judges), while the strategy of overruling leads to unstable legal rules that rarely converge to efficiency. We conjecture that the lawmaking rule of incrementalism may have similar efficiency-enhancing evolutionary properties to a rule of distinguishing.

21 The fixed costs may be especially pronounced in the context of WTO litigation, which frequently involves public-private partnerships between industry, private lawyers, and government lawyers and representatives. For a discussion, see Shaffer (2003). 
dispute-resolution system that can adversely affect efficient evolution of the law. For example, economic research provides empirical evidence suggesting high litigation costs contribute to explaining why poor countries are noticeably absent from formal participation in DSU litigation. ${ }^{22}$ While such research has thus far focused on the 'missing parties' (i.e., poor countries) involved in potential disputes, an additional concern is that 'missing issues' will fail to be resolved because litigation costs will prevent certain issues from coming forward for a legal opinion. Under an incrementalist approach to something like zeroing, one could imagine an iterative scenario in which the most 'economically important' zeroing issue (e.g., say, W-W in antidumping investigations) was brought forward first, followed by the second-most economically important, followed by the third, etc. The concern is that, if litigation costs are substantially high, the 12th (least economically important), 11 th, 10 th, ... issues may end up not getting legally resolved. What if the potential resource costs to litigation are so high that no one ever challenges zeroing using, say, the W-W method in a new-shipper review? The implication is a resulting inefficient and/or incomplete law. On the other hand, with a more comprehensive approach to decisionmaking, it is possible that legal issues that are nevertheless 'economically small' would also receive attention from jurists. In the presence of high resource costs of litigation, a comprehensive approach can be seen as creating a positive externality in that it clarifies the legality of (economically smaller) issues that would otherwise go unresolved under the incrementalist approach.

A second resource cost of incrementalism falls on the Dispute Settlement Body and the WTO institution itself. From an institutional perspective, there may be substantial fixed costs of establishing a panel, and thus there are economies of scale to litigating as many issues as possible within the context of the single panel. Grossman and Sykes (2006) have already provided an expansive discussion of this issue in the context of the consolidation of claims in a proceeding, and we will not repeat them here.

\section{Incrementalism and resource costs of industry adjustment}

In the context of the zeroing issue in particular, the incrementalist approach also creates costs for any industries or countries affected by what will ultimately be ruled to be a WTO-inconsistent use of zeroing in antidumping proceedings. A failure to clarify at the stage of EC-Bed Linen which zeroing methods were WTO-inconsistent meant that a number of imported products in the US (and other countries that use zeroing) continued to face illegal protectionist measures - either antidumping measures that would not have been imposed but for the zeroing methodology, or measures with levels biased upward relative to what they would

22 See, for example, the discussion in Bown and Hoekman (2005), as well as the empirical evidence found in studies such as Bown $(2005 \mathrm{a}, \mathrm{b})$. For our purposes, the concern is that the costs of litigation may make it economically irrational for a country to pursue a case even if there is a legal reason to do so. 
be in the absence of the ability to use zeroing. ${ }^{23}$ The resulting costs are by and large familiar.

First, the import protection associated with an illegal antidumping measure leads to the standard welfare-economic costs-consumers pay higher prices than they would otherwise have to, and the economy suffers from deadweight (efficiency) welfare losses relative to an outcome in which the measure is removed. These economic losses remain until the incrementalist approach ultimately eliminates each instance in which zeroing is ruled WTO-inconsistent and there is compliance.

Second, there are additional dynamic considerations in the face of a prolonged period of protection while the zeroing issue is incrementally being resolved. Of foremost concern is how the incrementalist nature of the approach affects the adjustment incentives of the industry currently benefiting from the (eventually) WTO-inconsistent protection. By prolonging the state of protection, the result may be a possibility of excess profits and an incentive for entry. If the market has no substantial entry barriers (vis-à-vis domestic resources, i.e. foreign entry cannot occur by assumption because of the protection), new investment may come into the industry to take advantage of the excess profit opportunity. ${ }^{24}$ Thus, the incrementalist approach can retard efficient industry adjustment (resource exit) by creating incentives for new investment.

In sum, incrementalism is a double-edged sword. It has clear advantages, but is not obviously the most efficient approach to adjudication in all circumstances. Other things being equal, incrementalism is less advantageous when the decisionmaker can anticipate that future disputes will arise over issues closely related to those in the dispute at hand, and when the decisionmaker has the ability to solicit briefs and arguments from interested parties on such issues. The WTO zeroing litigation poses a scenario that perhaps fits these conditions, although we are reluctant to weigh in too heavily on that proposition. If our suspicion is correct, however, one cannot but wonder whether the incremental approach to zeroing has led to unnecessary delay and litigation in the resolution of the issues associated with zeroing, and whether the attendant costs might have been averted or at least diminished had the Appellate Body taken a more aggressive approach to resolving the issues early in the process.

23 For this discussion, we rule out the possibility that antidumping authorities would find alternative WTO-inconsistent techniques resulting in the same bias; furthermore we rule out any issues of compliance.

24 While not within the context of antidumping, this phenomenon of industry churning while being heavily protected has been documented for the US textile industry in the empirical results of Levinsohn and Petropoulos (2001). The US steel industry is another example of a sector that has seen substantial investment from new entrants (mini-mills) that has contributed to within-industry churning and displacement of historical plants and workers, despite substantial protectionist measures being in place. Bown and McCulloch (2005) provide a discussion of antidumping as an 'anti-adjustment' policy more broadly. 


\section{Competing methods of overhead cost allocation}

A narrow issue in the dispute relates to how Commerce allocated the Canadian firm Abitibi's interest expenditure via its 'cost of goods sold' (COGS) method. Before turning to the practical difficulties in capital-cost construction in this particular dispute, it is important to identify the purpose of this accounting exercise from the perspective of economics: the goal is to construct a capital-cost measure that most closely reflects the opportunity cost of the capital input. ${ }^{25}$ The issue of how to appropriately construct proxies for capital costs in this context raises a number of questions.

The Abitibi issue involves the further question of how to construct appropriate measures when the entity is a conglomerate (multi-product) firm, and the firm's various products are differentially capital-intensive so that the average capital expense per dollar in sales is not necessarily representative of the capital expense per dollar in sales of the particular product under investigation. Under such a scenario, the economic question is what is the best proxy for the conglomerate firm's capital costs for the products subject to the antidumping investigation. A first suggestion is the following neutrality benchmark: we would not want a stand-alone softwood firm that is identical to the softwood division of a conglomerate to have different estimated capital costs. The practical question is then how can the conglomerate firm's capital allocation be done to ensure that consistency?

Commerce's utilization of the COGS method to allocate capital expenditures based on the share of cost of goods sold would only get this allocation correct by coincidence. ${ }^{26}$ In this particular case, it is not likely to allocate capital expenditures correctly when the conglomerate has substantially different capital intensities for its investigated versus non-investigated product lines. It seems to us that if the conglomerate's other products are relatively more capital intensive than softwood lumber (as Abitibi asserted) then the COGS method will overestimate the capital costs of the softwood-lumber line and serve to inflate the construction of overall costs and thereby the size of the dumping margin (relative to an otherwise identical, but stand-alone softwood-lumber firm).

25 This issue raises a broader question of whether financial statement information is useful to proxy for opportunity costs at all. Insight from research in corporate finance suggests that the answer to this question is no, and that to construct accurate, market-based measures requires a model-based estimate that would also allow for the influence of risk and return. Of course, this problem infuses all of antidumping law, which is based on accounting costs rather than economic costs.

26 Let COGS $S_{i}$ be cost of goods sold and $R_{i}$ be the cost of capital (interest) for the conglomerate with products $i \in I$. Then the COGS method for calculating the cost of capital for lumber is based on the following formula: $R_{\text {Lumber }}=\left(\sum_{i \in I} R_{i}\right)\left(\frac{\operatorname{COGS}_{\text {Lumber }}}{\sum_{i \in I} C O G S_{i}}\right)$, which is simply to allocate total capital costs (interest) to the share of cost of goods sold associated with lumber sales. Nothing in the formula relates interest expended on lumber to how much capital is used in lumber production relative to production of other goods in the conglomerate. 
Commerce asserted that this problem is not significant because if there is less capital used in softwood, it will show less depreciation expense, and that will result in a lower constructed cost for softwood. Without knowing more about exact accounting requirements and practices in this particular dispute, it is difficult to know whether Commerce is correct. First, what if the conglomerate only reports consolidated information on depreciation, so that depreciation expenses also cannot be allocated across different product lines? Second, even if depreciation expenses are reported for a particular product line associated with a distinct division, will those accurately reflect differences in capital intensity? To the extent that mandated depreciation rates differ according to the year of the capital expenditure and/or capital expenditures differ within the divisions over time, we have little confidence that the depreciation calculation will accurately reflect capital costs. We are also led to wonder whether these accounting methods will introduce biases according to whether the firm is financed with debt or equity.

Abitibi proposed an alternative method for allocating interest expense based on the relative amount of capital assets used by the various lines of production within the corporate group. Such an alternative methodology could lead to additional sources of concern. For example, a conglomerate firm may have an internal structure where one corporate division takes on the role of holding and leasing out capital assets to all of the other producing subsidiaries. If this were to be the case, the balance sheet of the producing subsidiary would also not reflect the value of the capital and the income statement would not reflect the depreciation on that capital, but instead some sort of lease payment that might or might not approximate opportunity costs.

Hence, there are potential problems with both the Commerce and Abitibi proposals, and we do not have sufficient information to say which method is better. And although an alternative method might be to use capital costs from a stand-alone softwood-products firm as a benchmark for the costs of a conglomerate such as Abitibi, finding a comparable firm might be exceedingly difficult.

\section{Transfer-pricing and the cost of production}

This section provides an economic analysis of one of the by-product revenue issues in Softwood V. As background, the Canadian firm Tembec faced much higher $(10.21 \%$ vs. $2.18 \%)$ final margins in the dumping determination than a competing Canadian firm, West Fraser. One of the contributing factors was Commerce's construction of the estimates of the revenue each firm received from its sale of wood chips, a 'by-product' in the production of softwood lumber. Wood chips have value as an input in downstream pulp and/or paper production. The key distinction between the two firms that is of interest to our analysis relates to how Commerce differentially treated within-firm (non-arm's-length) transactions 
of wood chips. ${ }^{27}$ For the case of West Fraser, Commerce treated the data on its internal-transfer price of wood chips as unrepresentative of their true value and instead used the price of its wood-chip sales made in arm's-length transactions to determine the total value of combined wood-chip sales made to affiliated and unaffiliated parties. In contrast, Commerce used Tembec's internal (within-firm) price for wood-chip sales to construct the value of by-product revenue. Since Commerce used the income from sales of by-product wood chips as an offset to each firm's costs of producing softwood lumber, Tembec's low transfer price for the within-firm sales contributed to it receiving a higher dumping margin. The Panel concluded that Commerce's determination did not violate the ADA, and the Appellate Body upheld the Panel's findings.

Canada's appeal on this issue raises the question of how to account appropriately for costs when there are concerns about reported data within a firm because of the potential manipulation of transfer prices. The issue highlights the importance of using the economic concept of opportunity cost to measure costs when calculating dumping, and the practical difficulty in doing so.

The economic literature suggests many potential reasons why firms set internal prices (for non-arm's-length transactions) that deviate substantially from the opportunity costs of the resources involved. One possibility is that the tax law has created incentives for firms to report 'artificially' low (or high) prices for a non-arm's-length transaction of wood chips from a lumber mill to a pulp mill. For example, a firm may have an incentive to underprice (overprice) the value of the transaction on its internal books if there are higher (lower) federal or provincial tax rates on income earned due to woodchip sales relative to income earned from timber sales. ${ }^{28}$

Yet another reason for transfer-price manipulation is suggested by the softwood dispute itself. Suppose a firm like Tembec properly anticipated that it would face a future antidumping investigation and dumping-margin calculation. If Commerce has signaled a likelihood of relying on reported internal prices, the firm would have a clear incentive to over-report the internal price of wood chips, ceteris paribus, as this serves to reduce the constructed cost measure and decrease the dumping margin on the investigated product.

If reported internal prices are potentially unreliable measures of the opportunity costs of by-products, what is a better proxy in practice? If the firm under

27 To clarify, we will not address the question of whether Commerce properly classified the firm's sales as non-arm's-length or arm's-length transactions, as we do not have enough information to do so. Nevertheless, as will become clear below, such an issue is not important for the point that we make regarding the necessity of evaluating the value of the wood chips based on their opportunity costs.

28 The industrial organization literature suggests other possibilities. For example, firms may use internal-transfer prices to create incentives for employees to overcome what economists refer to as a principal-agent problem. Such internal contracts may contain prices manipulated to induce optimal employee effort when there are monitoring costs or uncertainty generated by unobservable employee characteristics (e.g., 'skill'). 
investigation makes sales at arm's length to unaffiliated buyers, the prices in those sales will typically be a good indicator of opportunity costs. ${ }^{29}$ This is what we understand Commerce to have done with respect to West Fraser, and it is difficult to object to it. The harder question is why Commerce did not do the same for Tembec. If, indeed, Tembec's internal prices were in fact much the same as its prices to unaffiliated companies, of course, there can be little objection to the use of the internal prices. But it is obvious from the challenge brought by Canada that Tembec's internal prices were for some reason materially lower than the market-price benchmark. Commerce's unwillingness to shift to a market benchmark under these circumstances is suspect. Indeed, one infers that Commerce seems to choose between market prices and internal prices according to which choice yields the highest dumping margin. Even if such an approach is 'standard practice' for Commerce, it strikes us as quite illegitimate.

The legal distinction that the panel drew (and the Appellate Body accepted) between Tembec and West Fraser also rings hollow. At Tembec, all divisions involved in the by-product transaction were wholly owned. At West Fraser, by contrast, the by-product sales were between companies that were merely 'affiliated'. If anything, there is more reason to distrust internal-transfer prices in the case of Tembec than in the case of West Fraser, so that the use of a market benchmark for West Fraser but not Tembec seems indefensible. The mere fact that the two companies were 'differently situated' does not, in our view, provide an economically rational basis for the disparate treatment.

\section{Conclusion}

For the reasons developed above, we question the Appellate Body's approach to the zeroing issue in Softwood V. Although any decision that tends to reduce antidumping duties has some appeal from an economic standpoint, the legal foundation for the Appellate Body's ruling is somewhat dubious, doubly so in the face of the standard of review applicable under the ADA. The danger of such decisions is that they will undermine confidence in the Appellate Review process and make it more difficult for WTO members in the future to reach agreement on contentious issues. We also wonder whether the Appellate Body might have done more to ward off the extensive litigation over zeroing through more comprehensive decisions earlier in the process, although we are mindful of some offsetting

\footnotetext{
29 Another place to look for a proxy might be an arm's-length (market) transaction between two firms unrelated to the producer under investigation and to use this transaction price to value internal (withinfirm) sales of the by-product by the firm being investigated. A simple caveat to such an approach is that even an arm's-length transaction may fail to reflect opportunity costs if there are other substantial imperfections in this market. For example, if the arm's-length transaction takes place in the presence of market power-i.e., the lumber mill selling the pulp is a monopolist or the paper mill purchasing it is monopsonist - the revealed market price may also not be a good proxy for the opportunity cost of the wood chips. Likewise, it may be difficult to determine whether the market conditions facing the two unrelated firms are comparable to those facing the firm under investigation.
} 
considerations. Finally, with respect to the cost-allocation practices of Commerce that were at issue in the appeal, we find both of those practices to be questionable.

\section{References}

Boltuck, Richard and Robert E. Litan (eds.) (1991), Down in the Dumps, Washington, DC: The Brookings Institution Press.

Bown, Chad P. (2005a), 'Trade Remedies and World Trade Organization Dispute Settlement: Why Are So Few Challenged?', Journal of Legal Studies, 34: 515-555.

Bown, Chad P. (2005b), 'Participation in WTO Dispute Settlement: Complainants, Interested Parties and Free Riders', World Bank Economic Review, 19: 287-310.

Bown, Chad P. and Bernard M. Hoekman (2005), 'WTO Dispute Settlement and the Missing Developing Country Cases: Engaging the Private Sector', Journal of International Economic Law, 8: 861-890.

Bown, Chad P. and Rachel McCulloch (2005), 'US Trade Policy and the Adjustment Process', IMF Staff Papers, 52: 107-128.

Dam, Kenneth W. (1970), The GATT: Law and International Economic Organization, Chicago, IL: University of Chicago Press.

Gennaioli, Nicola and Andrei Shleifer (2007a), 'The Evolution of Common Law', Journal of Political Economy, 115: 43-68.

Gennaioli, Nicola and Andrei Shleifer (2007b), 'Overruling and the Instability of Law', Journal of Comparative Economics, 35 : 309-328.

Grossman, Gene M. and Alan O. Sykes (2006), 'European Communities - Anti-Dumping Duties on Imports of Cotton-Type Bed Linen from India: Recourse to Article 21.5 of the DSU by India', in Petros C. Mavroidis and Henrik Horn (eds), The WTO Case Law of 2003, Cambridge: Cambridge University Press.

Janow, Merit E. and Robert W. Staiger (2003), 'European Communities - Anti-Dumping Duties on Imports of Cotton-Type Bed Linen from India', in Petros C. Mavroidis and Henrik Horn (eds), The WTO Case Law of 2001, Cambridge: Cambridge University Press.

Levinsohn, James and Wendy Petropoulos (2001), 'Creative Destruction or Just Plain Destruction?: The US Textile and Apparel Industries Since 1972', NBER Working Paper 8348.

Shaffer, Gregory C. (2003), Defending Interests: Public-Private Partnerships in WTO Litigation, Washington, DC: The Brookings Institution Press.

Sykes, Alan O. 1998. Antidumping and Antitrust: What Problems Does Each Address?, in Robert Lawrence (ed.), Brookings Trade Forum 1998, Washington, DC: The Brookings Institution Press. 